\title{
Educação Física escolar e ditadura militar no Brasil (1968-1984)história e historiografia
}

\author{
Marcus Aurélio Taborda de Oliveira \\ UniversidadeFederal do Paraná
}

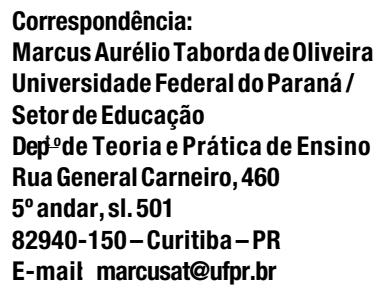

\section{Resumo}

Neste artigo pretende-se indicar um conjunto de procedimentos oficiais, institucionais e profissionais, que produziu uma nova forma de conceber a educação física no interior da instituição escolar no Brasil, desde o final dos anos 1960, com base em um diálogo crítico com a recente produção historiográfica da educação e da educação física no Brasil.

Aqueles procedimentos foram orientados no sentido de dotar essa prática escolar de uma maior legitimidade acadêmica por meio de um amplo programa de massificação de seus conceitos e práticas, de maciços investimentos estatais em pesquisa nessa área, da necessidade de formação de especialistas mediante a expansão dos cursos de formação superior, e de um aparato legislativo que definia com rigor padrões de referência para a sua prática escolar. Para tanto, suas fontes principais são: a série total da Revista Brasileira de Educação Física e Desportos(1968-1984), editada pela Divisão de Educação Física do MEC, os Programas de Educação Física da Prefeitura Municipal de Curitibaentre 1970 e 1984 e os depoimentos de professores da rede municipal de ensino de Curitiba.

Partindo do pressuposto de que o processo histórico se define como uma síntese de continuidade e ruptura, recorre à obra de Edward Palmer Thompson para demonstrar como aquele se desenvolve a partir da experiência dos agentes da história e do diálogo entre o ser social e a consciência social, sem negligenciar a análise da influência dos fatores estruturais sobre esse mesmo processo, aspecto privilegiado pela historiografia criticada.

\section{Palavras-chave}

História da educação física escolar - Ditadura militar - Disciplinas escolares. 


\section{Physical education at school and the military dictatorshipinBrazi(1968-1984): his to ry and his to rio graphy}

Marcus Aurélio Taborda de Oliveira

Universidade Federal do Paraná

Correspondence:

Marcus AurélioTaborda de Oliveira Universidade Federaldo Paraná/ Setorde Educação Dep ${ }^{\circ}$ de Teoria e Prática de Ensino Rua General Carneiro, 460 $5^{\circ}$ andar, sl. 501 82940-150-Curitiba-PR E-mail:marcusat@ufpr.br

\section{Abstract}

This paper describes a set of official, institutional and professional procedures that, since the late sixties, produced a new way of conceiving the physical education within the school in Brazil; to this end, a critical dialogue is effected with the recent historiography literature on education and physical education in Brazil.

The aforementioned procedures were geared towards endowing the physical education with greater academic legitimacy through a series of measures: a wide program of massification of its concepts and practices, massive state investments in research in this field, the need to train specialists through the expansion of higher education courses, and the creation of a legal apparatus that defined rigorously the standards of its practice at school. To such effect, the paper's main sources are the complete series of the Revista Brasileira de Educação Física e Desportos (Brazilian Journal of Physical Education and Sports (1968-1984), edited by the Physical Education Division of the Ministry of Education (MEC), the Programas de Educação Física (Programs of Physical Education) from the Municipal Government of Curitiba between 1970 and 1984, and statements given by teachers of the municipal school system of Curitba.

Considering that the historical process is defined as a synthesis of continuity and rupture, the work of Edward Palmer Thompson is drawn upon to show how this process develops from the experience of history's agents and from the dialogue between the social being and the social conscience, without overlooking the analysis of the influence of structural factors, an aspect privileged by the historiography criticized.

\section{Keywords}

History of Education - Physical Education - Military dictatorship - School disciplines. 


\section{Educação física escolar e ditadura militar no Brasil: o que nos fala a historiografia?}

Segundo uma determinada produção acadêmica da área da educação física a partir da década de 1980, de forte acento crítico, com a qual discutirei ao longo desse trabalho, a educação física escolar foi conformada de forma autoritária pelo Estado no Brasil, a partir das reformas educacionais de 1968 (Lei 5.540) e 1971 (Lei 5.692 e decreto 69.450). Segundo as análises oriundas desses estudos, no interesse do desenvolvimento de um maior grau de eficiência produtiva no mundo do trabalho e, pressupondo a importância da educação escolarizada para se atingir este fim, a tecnicização do ensino patrocinada pelo governo teria como premissa básica a disciplinarização, a normatização, o alto rendimento e a eficácia pedagógica. Esse pressuposto seria orientado pelo alinhamento do país a uma ordem mundial calcada no desenvolvimento associado ao capital internacional, mais explicitamente, ao norte-americano. Segundo tal concepção, é irrefutável a tese da dependência estrutural, o que implica necessariamente a dependência cultural, aí incluída a educação em geral e, no âmbito deste trabalho, a educação física escolar em particular.

Dentro dessa perspectiva os intelectuais a serviço do governo teriam gestado as políticas públicas para a educação no período aqui abordado. Para a educação física escolar a Lei 5.692/71 reserva, em seu artigo 7, um espaço de obrigatoriedade nos currículos escolares. Essa obrigatoriedade foi regulamentada com o Decreto $69.450 / 71$, que impôs padrões de referência para a prática de educação física no interior da escola, caracterizada como atividade, ainda que a educação física passasse a ter todos os pressupostos característicos da configuração de uma disciplina escolar (Chervel, 1990).

Segundo uma interpretação corrente na historiografia, o esporte, aliado à interfe- rência governamental no desenvolvimento da educação física escolar, tornava-se referência praticamente exclusiva para a prática de atividades corporais no plano mundial, seja dentro ou fora da escola. Isso teria ocorrido, em parte, porque numa certa perspectiva o esporte codificado, normatizado e institucionalizado pode responder de forma bastante significativa aos anseios de controle por parte do poder, uma vez que tende a padronizar a ação dos agentes educacionais, tanto do professor quanto do aluno; noutra, porque o esporte se afirmava como fenômeno cultural de massa contemporâneo e universal, afirmando-se, portanto, como possibilidade educacional privilegiada. Assim, o conjunto de práticas corporais passiveis de serem abordadas e desenvolvidas no interior da escola resumiu-se à prática de algumas modalidades esportivas. As práticas escolares de educação física passaram a ter como fundamento primeiro a técnica esportiva, o gesto técnico, a repetição, enfim, a redução das possibilidades corporais a algumas poucas técnicas estereotipadas.

Essas são algumas das teses da historiografia. Mas teriam os professores de educação física adotado passivamente os pressupostos teóricos e metodológicos para a educação física escolar difundidos pelo Estado e divulgados pela Revista Brasileira de educação física e Desportos (periódico do MEC com ampla circulação nacional), ou a prática cotidiana da educação física escolar desenvolveuse com uma autonomia relativa ante as orientações de um governo autoritário? As evidências empíricas, a serem exploradas ao longo deste artigo, não permitem respostas esquemáticas para essa questão.

Tais suposições, ainda que não sejam de todo descartadas, carecem freqüentemente de uma análise empírica mais acurada. Se, por um lado, a partir de meados da década de 1970, a produção acadêmica em educação física começava a se desenvolver com critérios científicos, principalmente pelo início de um processo de titulação (mestrado e doutorado) 
de seus profissionais e pela emergência dos primeiros cursos de pós-graduação no Brasil, por outro lado, já estava sendo produzida e discutida no âmbito educacional uma literatura baseada nas teorias críticas, com as quais os profissionais da educação física travaram contato tardio, uma vez que essas teorias só foram apropriadas pela teoria da educação física no início dos anos 1980. Esses dois movimentos infirmam a tese de um transplante puro e simples de teorias estrangeiras. As evidências mostram que havia embates bastante significativos em torno da questionável importância do esporte como prática pedagógica, o que ocorria até mesmo no interior de um periódico do MEC.

A historiografia desenvolveu uma estreita interpretação que imputa à educação física escolar uma função de reprodução do ideário oficial, calcado na ideologia da segurança nacional e do Brasil grande. Além disso, a tecnicização das práticas corporais representaria melhoria das condições da força de trabalho, no sentido de torná-la mais eficiente e eficaz no processo de produção; a racionalidade e o planejamento da economia da educação conformavam, então, as políticas públicas e, conseqüentemente, as práticas escolares, deixando pouco ou nenhum espaço para a intervenção dos sujeitos na história.

Essa visão está fortemente influenciada pela perspectiva de um a prioriestruturaleconomicista nas relações do governo com a sociedade civil, atuando aquele como mediador dos interesses entre o capital e o trabalho, para garantir a acumulação ampliada do primeiro. 0 "Estado" é concebido como uma instância que paira acima dos conflitos e dos consensos e determina a prática e os interesses cotidianos dos sujeitos na história. Essa perspectiva marca ainda uma profunda crença na última instância da estrutura econômica como orientadora da organização da cultura e das práticas culturais em particular, como é o caso da educação escolarizada.

Ora, como conceber os sujeitos histớ i cos como indivíduos incapazes de gerir o seu cotidiano ou, de forma ainda mais radical, como massa de manobra apenas e sempre? Isso eqüivaleria a extrair do sujeito toda a sua autonomia, ainda que relativa, em face das vicissitudes da vida social e toda sua capacidade de indignação e resistência diante dos modelos preconcebidos de organização da cultura. Assim, ao operar com as evidências não foi difícil refutar uma leitura determinista e economicista do materialismo histórico, característica de uma determinada leitura da história, que extrai dos sujeitos toda sua potência criadora e os reduz a pouco mais que simples insumos culturais. Nessa perspectiva os agentes históricos não teriam qualquer possibilidade de mover-se com autonomia diante das rígidas estruturas ideológicas determinadas pelo Estado. Moldar-se a determinados modelos culturais impostos de forma imperativa seria então tudo o que restaria aos mais diversos sujeitos.!

Essa perspectiva da história da educação física foi marcada por uma visão linear, um tanto mecânica, desenvolvida no âmbito da pesquisa em história da educação no Brasil a partir da década de 1970 a qual, por sua vez, se alimentou das discussões desenvolvidas no interior das Ciências Sociais. Assim, um dos objetivos deste artigo é evidenciar os limites desse tipo de abordagem, tendo como referência para análise uma determinada produção teórica da história da educação no Brasil a partir da década de 1970 e a influência desta produção mais ampla sobre a pesquisa em educação física no Brasil a partir da década de 1980. Já existe um acumulo significativo de estudos que fazem a crítica da produção historiográfica da educação brasileira, motivo pelo qual resolvi deter-me exclusivamente na produção historiográfica da educação física escolar. Mas trabalhei sempre tendo no horizonte as obras de Vieira (1983), Libâneo (1989),

1. A pesquisa que deu origem a este trabalho resultou na minha tese de doutorado em História e Filosofia da Educação, defendida em março de 2001 junto ao Programa de Estudos Pós-Graduados em Educação: História, Política, Sociedade, da PUC/SP, sob a orientação do prof. dr. Kazumi Munakata. Para um maior aprofundamento dos pressupostos e procedimentos por mim adotados ver Oliveira (2001). 
Freitag (1986), Saviani (1987, 1988, 1989), Buffa e Nosela (1991), Germano (1993), Cunha e Góes (1994) e Guiraldelli Jr. (1994). Na perspectiva de crítica a essa produção, bem como a outros estudos aqui não referidos, o leitor tem à disposição os trabalhos de Rashi (1990), Aranha (1992), Azanha (1992), Vieira (1994) e Barreira (1995).

A escolha de obras e autores da educação física deu-se pela conjugação de dois fatores distintos: a) a crítica aos modelos (políticas) gestados pelo Estado naquele período e b) a utilização de um referencial de análise que tenha como objeto privilegiado a educação escolar. Esse recorte se faz necessário para precisar o alcance e os limites do trabalho ao qual me proponho: primeiro, traçar um quadro do quanto foi restrita a análise da dimensão social, política, econômica e cultural brasileira, sob a ótica de uma tradição de pesquisa comprometida com a transformação da educação escolar brasileira em geral e a educação física escolar em particular, a partir da década de 1980. E, segundo, buscar recolocar a questão das análises das práticas escolares, particularmente da educação física, na nossa história recente, a partir de um olhar para dentro da escola, devolvendo aos sujeitos o seu lugar na história da educação física escolar no Brasil.

\section{Leituras sobre a história da educação física brasileira.}

Ao caracterizar esse tópico como leituras pretendo deixar claro que não foi meu intento esgotar a análise da produção historiográfica referente ao periodo em questão. Trata-se antes de uma leitura possível de obras datadas e situadas. Com isso pretendo alertar o leitor que não é a minha intenção abarcar o conjunto da obra dos autores aos quais me reporto, mas apenas debater com algumas obras escolhidas, seja pelo seu forte impacto na área da educação física escolar, seja pela sua caracteristica fundamentalmente histórica. Assim é que os textos escolhidos, antes de se configurarem como um todo homogêneo, caracterizam-se mais como entradas possíveis de leitura na história recente da educação física no Brasil, a partir de uma orientação crítica. Em comum esses trabalhos trazem um determinado olhar sobre a história e a produção humana com algumas nuanças, mas caracterizados basicamente por uma forma vertical de conceber a relação entre os sujeitos históricos e as estruturas sociais, políticas e econômicas. Muitos desses trabalhos não se caracterizam sequer como estudos históricos. Mas fazem inserções nesse campo, o que permite leituras e interpretações de caráter histórico. Esse foi o meu intento: com base nas indicações históricas dadas por esses autores que freqüentam com assiduidade os cursos de formação de professores e a produção acadêmica da área - motivos mais do que suficientes para o estabelecimento de um diálogo crítico - procurei captar e indicar um determinado esquema interpretativo das relações entre o ideário oficial e as práticas cotidianas dos agentes educacionais, presente na produção acadêmica da educação física no Brasil a partir do início da década de 1980.

Desde a chegada das teorias críticas educacionais à área de educação física no Brasil na década de 1980, seus pesquisadores têm afirmado que ela se encontra em crise (Medina, 1983; Carmo, 1985; Guiraldelli Jr, 1988; Mariz de Oliveira, 1988; Bracht, 1992; Tani, 1998). Mais notadamente no âmbito escolar, a educação física tem sido considerada como uma disciplina sem um lugar muito claro na escola. Muitos pesquisadores caracterizam-na como uma atividade sem legitimidade (Bracht, 1992), sem função social (Betti, 1991; Coletivo de Autores, 1992), sem função política (Guiraldelli Jr, 1988) e até mesmo sem função educativa (Mariz de Oliveira, 1988) no interior da escola. Todos esses estudos caracterizam-se por 
uma visão estrutural extremamente ampla e um tanto arbitrária: a educação física estaria em crise porque - dentre outras razões - o governo autoritário instalado no Brasil após 1964, na tentativa de consolidar sua ideologia, fez uso das atividades desportivas (e da educação física em geral) com a finalidade de anestesiar a consciência e amainar a participação popular nos processos reivindicatórios e decisórios. Então, teria o governo produzido e divulgado uma certa abordagem de educação física que se consolidou de forma incontestável, sem que os profissionais da área pudessem contrapor-se às suas medidas arbitrárias e autoritárias.

A primeira dificuldade que apareceu ao tentar recortar a história da educação física no período aqui proposto diz respeito à limitada produção historiográfica da área, principalmente sobre o período por mim estudado: é praticamente inexistente na historiografia qualquer trabalho que faça referência ao período aqui proposto. À exceção do estudo de Lima (1992), desconheço trabalhos de maior densidade sobre essa temática. Já existe na historiografia da educação física brasileira um grande número de estudos em torno da influência militar sobre a educação física (Goellner, 1996; Bercito, 1996; Castro, 1997; Ferreira Neto, 1999). Mas ainda não foram produzidos trabalhos que se refiram especificamente ao período da ditadura militar. Assim, a aproximação histórica deu-se por recortes feitos a partir de outras obras consagradas na área, mas que não se caracterizam por serem estudos históricos, necessariamente. No seu conjunto tais estudos dizem respeito muito mais às práticas escolares do que à história propriamente dita. Mas todos eles, de uma maneira ou de outra, recorrem à história para justificar posições, construir interpretações e alguns até mesmo estabelecer prescrições.

Nesse sentido é importante destacar que esse conjunto de obras analisado perfaz o caminho já apontado por Warde (1990), uma vez que, ainda que não sejam trabalhos próprios de história da educação física, neles “a história é chamada para justificar algo" (p. 9). Segundo a autora, um traço característico de trabalhos dessa natureza é "o recuo a períodos históricos passados [que] serve para mostrar que o presente é do jeito que é porque o passado foi o que foi" (1990, p. 9). A minha opção por tal operação poderia representar riscos, não fosse a grande influência que essas obras lograram conquistar junto à comunidade acadêmica e, em muitos casos, junto aos currículos oficiais e aos professores. Ora, essa influência acaba por reforçar leituras históricas de segunda mão, mesmo que os estudos de caráter histórico não fossem o interesse primeiro dos autores das obras arroladas. Assim, para criticar as práticas escolares de educação física, vários autores recorreram a um mergulho na sua história, indicando linhas de continuidade entre o que foi e o que tem sido a educação física escolar neste país.

Certamente a obra de Castellani Filho (1988) marca uma ruptura com as leituras anteriores da história da educação física no Brasil, mas pouco inova no sentido do método. Com uma base teórica marcadamente avançada para a época em que foi produzido, Castellani Filho reescreve a história, porém, nos velhos moldes lineares, causais. Ainda assim, sua análise traz para a cena o conflito inerente a uma sociedade de classes, o que representa um avanço relativo perante uma forma asséptica de conceber a relação da educação física com a cultura. Traçando um paralelo constante entre educação e educação física escolar, Castellani Filho procura demonstrar o caráter marcadamente reprodutivista da educação física escolar brasileira (p. 124). Fiel às teorizações críticas baseadas na relação de causa e efeito entre a estrutura e a superestrutura, o autor denuncia também o caráter de continuidade das propostas educacionais do Estado nas décadas de 1960 e 1970 e a tecnicização da educação em geral e da educação física escolar em particular, como adequação ao modelo de desenvolvimento econômico adotado pelo Brasil. Faz críticas à 
caracterização da disciplina escolar educação física como atividade e não como campo de conhecimento (p. 108). Critica também os pressupostos da educação do físico e da esportivização como afeitos a um modelo hegemônico no plano das relações internacionais de dependência aos quais o Brasil se submete (p. 114). Em linhas gerais, então, o texto de Castellani Filho tem sua tônica baseada na denúncia, na crítica, em um mergulho nos documentos legais e em pouca ou nenhuma preocupação em torno da real consolidação das políticas públicas no interior da escola. Sua obra se caracteriza por uma visão da gestação conspiratória de políticas públicas nos interesses escusos do capitalismo dependente.

Fruto de uma mesma tradição crítica, embora não se caracterize como um trabalho histórico, o trabalho de Bracht (1992) faz incursões por esse campo. Segundo minha interpretação, a obra de Bracht significa mais uma reedição de categorizações macroes-truturais, descarnadas da concretude histórica, segundo sua própria formulação. Bracht parte de uma análise da vinculação da educação física escolar com as instituições médica, militar e esportiva para tecer considerações acerca de uma possivel autonomia pedagógica da área. Seus apontamentos indicam a indefinição do papel do professor de educação física escolar, bastante útil para a consolidação do modelo pedagógico prevalecente nos anos da ditadura militar:

Essa orientação parece, mais uma vez, adequar-se bem à orientação tecnicista que, principalmente nas décadas de 60 e 70, predominam no sistema educacional brasileiro, sob a égide da ditadura militar, do projeto "Brasil-Grande". (Bracht, 1992, p 23-24)

A crítica de Bracht avança ao apontar a redução das possibilidades educativas da educação física na escola. Contudo, al- guns aspectos chamam a atenção. Em primeiro lugar é útil destacar a recorrência às teorizações de Saviani no seu trabalho, o que marca claramente uma tendência de pesquisa na educação física brasileira; em segundo lugar, a vinculação até certo ponto mecânica da educação física escolar com um projeto nacional de desenvolvimento; finalmente, a afirmação de que o lúdico perdeu espaço para as "tarefas mecânicas”. Essa interpretação apresenta problemas, uma vez que me parece inexato falar em substituição do lúdico pelo mecânico nesse período, a menos que a pesquisa histórica pudesse indicar sobre que bases - lúdicas ou mecânicas - se assentava a educação física no período anterior à ditadura militar. Hoje começam a despontar trabalhos que podem lançar algumas luzes sobre esse debate (Sousa e Vago, 1997; Vago, 1999). Mas Soares (1998) já demonstrou que a educação física nasceu sob o signo da técnica e do rendimento, mesmo em solo europeu. E o próprio autor aponta que a história da educação física brasileira está marcada por uma visão funcional e utilitarista (saúde, adestramento físico, etc.). Então soa como exagero imputar à ditadura militar a substituição na escola de uma prática lúdica por outra baseada na técnica. Para Bracht, para que a educação física escolar possa autonomizarse em relação ao esporte faz-se necessária uma "reflexão crítica do próprio papel da Escola em nossa sociedade de classes" ( $p$. 24), o que parece exato. Em sua perspectiva a educação física escolar acaba por ser "fator de reprodução das relações sociais dominantes, e assim, somente serão - os objetivos e conteúdos da educação física radicalmente questionados quando as pró-prias relações sociais vigentes o forem" (p. 24).

Os esforços do autor para desenvolver uma teoria (crítica) da educação física, no meu entender, esbarram em algumas contradições. Ao apontar que a "verdadeira educação física é aquela que acontece concretamente, e não 
uma entidade metafísica que estaria hibernando em algum recanto à espera de sua descoberta” (p. 35), e ao afirmar em seguida que a educação física "está relacionada, direta ou indiretamente, com as necessidades do projeto educacional hegemônico em determinada época, e com a importância daquela manifestação no plano da cultura e política em geral" ( $p$. 36), parece-me que Bracht não contrapõe a realidade efetiva do cotidiano escolar e as configurações das políticas educacionais. Ora, a "verdadeira educação física", aquela que efetivamente acontecia (ou não acontecia) em nossas escolas, não era a mesma propugnada pelas políticas públicas dos governos de plantão. Ou seja, não existia a "verdadeira" educação física, assim como continua a não existir, mas diferentes práticas escolares de educação física. 0 autor abstrai ainda a experiência concreta dos agentes sociais ao discutir a dimensão do esporte na escola e do trabalho como categoria não fundante da prática pedagógica.

Relativizando o conceito de trabalho, Bracht vai indicar que a "utilidade da educação física advém do seu caráter inútil” (p. 51). Tenho dúvidas quanto à efetividade desse postulado. Os limites dessa assertiva não serão analisados aqui, uma vez que requer um outro ângulo de compreensão. Apenas chama a atenção a incoerência da relativização do conceito de trabalho efetuada por Bracht, uma vez que faz uma opção clara pelo suporte teóricoconceitual do materialismo-histórico-dialético em suas análises. Ocorre que Bracht acaba por tentar conformar o cotidiano da escola a uma série de categorizações estabelecidas a priori Ainda que o autor visualize e critique a educação física em sua inegável negatividade, ele acaba por incorrer numa análise por demais abstrata quando fala de uma escola transformadora, de mudança social, de escola de classes. Assim, se aproxima de concepções muito difundidas nas teorias críticas da educação no Brasil, que estabelecem críticas de caráter marcadamente estrutural: a escola reproduz a sociedade burguesa (p. 74), a escola é autoritária (p. 79), a tecnicização da educação física escolar tem o sentido estreito de preparar para o trabalho (p. 61). Nessa perspectiva, parece não haver nenhuma possibilidade de uma cultura produzida a partir da escola, uma vez que a escola seria conformada a partir dos interesses da "classe burguesa".

De forma bastante fecunda os estudiosos da história das disciplinas escolares têm mostrado o quão infrutífera é uma análise baseada somente nas determinações que a escola sofre de fora para dentro. A escola tem sido cada vez mais reconhecida como um espaço de contradição, capaz de produzir práticas singulares a partir da experiência dos seus agentes, o que não confirma a tese de possiveis transposições mecânicas para o seu interior. Ou seja, esses estudos têm enfatizado que a instituição escolar não existe em abstrato; cada escola, uma realidade; cada realidade, diversas formas de conceber os embates e conflitos reais. A escola produz uma cultura muito própria, filtrando as determinações extra-escolares ou assimilando-as conforme suas necessidades e conveniências (Chervel, 1990; Goodson, 1990, 1991, 1995a, 1995b, 1995c; Belhoste, 1995; Chevallard, 1998).

$\mathrm{Na}$ mesma linha de raciocínio de Bracht, Coletivo de Autores (1992) também apontam para uma perspectiva de denúncia de modelos reprodutivistas de educação física através da história:

A perspectiva da educação física escolar, que tem como objeto de estudo o desenvolvimento da aptidão física do homem, tem contribuído historicamente para a defesa dos interesses da classe no poder, mantendo a estrutura da sociedade capitalista.

Apoia-se nos fundamentos sociológicos, filosóficos, antropológicos, psicológicos e, enfaticamente, nos biológicos para educar o homem forte, ágil, apto, empreendedor, que disputa uma situação social privilegiada na sociedade competitiva de livre concorrência: a capitalista. Procura, através da educação, 
adaptar o homem à sociedade, alienando-o da sua condição de sujeito histórico, capaz de interferir na transformação da mesma. Recorre à filosofia liberal para a formação do caráter do indivíduo, valorizando a obediência, o respeito às normas e à hierarquia. Apoia-se na pedagogia tradicional influenciada pela tendência biologicista para adestrálo. Essas concepções e fundamentos informam um dado tratamento do conhecimento. Nessa linha de raciocínio pode-se constatar que o objetivo é desenvolver a aptidão física. 0 conhecimento que se pretende que o aluno apreenda é o exercício de atividades corporais que lhe permitam atingir o máximo rendimento de sua capacidade física. Os conteúdos são selecionados de acordo com a perspectiva do conhecimento que a escola elege para apresentar ao aluno. (Coletivo de Autores, 1992, p. 36)

Esta citação traz elementos fundamentais daquilo que estou identificando como generalizações e abstrações. Em primeiro lugar, parte da constatação de que existe uma sociedade capitalista e, não, manifestações particulares do modo de produção capitalista. Afinal, uma tese genérica de conformação ao capitalismo corre o risco de incorrer em equívocos básicos: primeiro, abstrair o que viria a ser o capitalismo, concebido de forma indistinta para toda e qualquer formação social, o que implica abrir mão de matizes culturais próprios; segundo, transplantando, bem ao gosto das "camisas de força" teóricas, uma explicação universal que, contraditoriamente no interior da obra analisada, nega uma explicação própria para o processo de formação e organização da cultura brasileira. Assim, a explicação macroestrutural para o que viria a ser a vinculação da educação física escolar aos ditames do capitalismo parece-me uma forma profunda de redução da compreensão da organização da cultura. Mas, além desse aspecto por si só limitador, o texto também permite criticar sua desvinculação com o processo de interação e produção que se dá no interior da escola. Teria mesmo o esporte todo o potencial descrito acima para conformar de maneira tão acintosa os sujeitos a um determinado modo de produção, nesse caso, o capitalista? $\mathrm{Ou}$ isto é uma outra forma de abstração acadêmica? Em que medida a escola (e o professor) tem poderes para definir como se formará, enfim, o caráter do educando por intermédio do esporte? 0 esporte que acontece dentro da escola (se acontece!) é o mesmo regido pela indústria de entretenimento, pelos massmedia? Teria o professor que atua no cotidiano da escola consciência ou mesmo intenção de adestrar os alunos? Dividiria ele essa afirmação de que sua perspectiva de educação física escolar se baseia em uma filosofia liberal? Ora, quando no texto os autores afirmam que o sistema capitalista recorre à filosofia liberal para formar o caráter do indivíduo valorizando a obediência, o respeito às normas e à hierarquia, esquecem de matizar as teses básicas do próprio liberalismo ao longo do seu desenvolvimento histórico. São muitas as questões, e a minha intenção aqui não é respondê-las, mas questionar a validade de averbações tão peremptórias. No trato com as fontes históricas, mais notadamente a Revistae depoimentos de professores, ficam patentes as diversas impressões acerca do fenômeno esportivo e de sua utilização com fins pedagógicos, como poderemos ver mais adiante.

Mas voltando às considerações do Coletivo de Autores (1992), não é precipitado advogar que o objetivo dessa concepção (do Estado) seria o "máximo rendimento", ainda mais quando temos claro que render bem não significa necessariamente fazer o jogo do capital? Ora, a exigência de render de maneira produtiva e eficaz implica a necessidade de competência na produção das condições de existência humana mais dignas para o conjunto dos homens e mulheres, num mundo menos opressivo. Atuarmos nessa perspectiva e exigirmos do educando que faça o mesmo, não representa fazer o jogo do capitalismo ou do li- 
beralismo. Se a aptidão física é um reducionismo canhestro, a justificativa do texto citado para sua superação soa um tanto quanto exagerada.

0 Coletivo de Autores (1992) instaurara uma ruptura com uma determinada maneira de pensar a educação física escolar no Brasil, a partir, principalmente, da radicalidade com que aponta para o conflito como categoria fundante da prática pedagógica. Mas esbarra nos limites da denúncia, da abstração e da generalização. Suas proposições metodológicas pouco avançam no sentido daquilo que é tradicionalmente concebido como organização escolar; falta-lhe a concretude da sala de aula na sua análise, e, sobretudo, acredito que o espaço que reserva aos sujeitos históricos não se encontra na realidade, mas antes na teoria Por outro lado, analisando ainda esse mesmo texto e recorrendo ao pensamento gramsciano, algumas afirmações e constatações apontam para a negação de próprio suporte teórico da obra referida. Se considerarmos o processo histórico como dialético e a sociedade civil (e a escola aparece como aparelho privado de hegemonia) como campo de correlação de forças, a escola não apenas atuaria mantendo a estrutura da sociedade capitalista como também representaria uma possibilidade de confronto e crítica e construção da contrahegemonia. Além disso, o Coletivo de Autores abre mão da historicidade para operar uma crítica histórica.

Outro trabalho que aponta na mesma direção é o de Gabriel Humberto Muñoz Palafox. Traçando críticas ferinas à configuração da política nacional de ciência e tecnologia para a área de educação física no período da ditadura militar, o autor refaz o percurso já delineado pelos autores precedentes, no que diz respeito a uma total subserviência da sociedade civil à sociedade política. Sua leitura da constituição do CBCE parece-me um exercício de análise trans-histórica. Palafox caracteriza a entidade como
Uma entidade ligada à ideologia gerada e difundida pelo aparato estatal pós-64, onde o "novo" racionalismo teria (...) "um colorido mais técnico, atuando, de um lado, como elemento de desmobilização política da sociedade civil e, de outro, como fundamento das medidas estatais de estabilidade política e crescimento econômico" (...). Isto devido, entre outras razões, ao fato de que desde 1967, (através da Doutrina MacNamara) foi estipulado que a estabilidade (segurança) dos países latino-americanos seria garantida pelo seu desenvolvimento econômico apoiado, invariavelmente, no seu potencial de crescimento científico e tecnológico (...).

Reforçando estes fatos podemos constatar a tendência inicial, da linha de pensamento científico de origem positivista proveniente dos Estados Unidos, com o que o CBCE se fundara no início de suas atividades, uma vez que seus fundadores estabeleceram, como metodologia de trabalho (veja, por exemplo, suas normas de publicação científica), as especificações de uma entidade de cunho eminentemente racionalista, o denominado American College os Sports Medicine. (Palafox, 1990, p. 44-45)

Nas suas considerações Palafox abre mão de historicizar suas análises, o que implica formular uma interpretação da história sem a devida contextualização histórica. No campo específico da educação física, a análise e as críticas em torno da fundação do CBCE também reclamam uma maior historicidade. Ora, o CBCE como entidade científica só poderia se constituir dentro dos cânones da ciência. Acusar uma entidade científica de ser racionalista só pode soar como equívoco: como poderia uma entida-

20 Colégio Brasileiro de Ciências do Esporte é a maior e mais significativa entidade de cunho acadêmico-científico da área de Educação Física no Brasil. 0 leitor encontrará uma análise rigorosa da criação e consolidação do Colégio Brasileiro de Ciências do Esporte, inclusive no sentido de infirmar algumas das considerações de Palafox, no trabalho de Paiva (1994). 
de científica abrir mão da racionalidade na construção do conhecimento científico?

0 fato de a entidade que se constituía aliar-se a uma entidade americana "de cunho eminentemente racionalista" não implica, necessariamente, fazer o jogo da dominação. Acredito que naquele momento histórico a criação de uma entidade científica para a educação física no Brasil implicava o avanço técnico e científico da área, aspecto bem afeito à política desenvolvimentista do período. Mas a interpretação de Palafox faz identificar um certo reducionismo no plano da organização da cultura; afinal, entendida como uma das possibilidades, a criação daquele colégio não desqualifica a entidade e seus fundadores como pesquisadores preocupados com o avanço da área no Brasil. A sua perspectiva foi a vencedora em um campo de tendências. 0 autor parece trabalhar com a idéia de que só existe uma única razão "verdadeira"; nesse caso, que razão seria essa?

Porém, mais contundente nas formulações teóricas do autor, é sua defesa da vitimização dos professores em face dos desdobramentos das políticas educacionais do período: "o docente de educação física, como outros profissionais nesta sociedade de classe, tem sido também vítima das mais diferentes formas de violência ideológica do sistema capitalista vigente" (p. 101). Já destaquei que não é minha intenção absolutizar as possibilidades dos sujeitos na construção da história; tampouco absolver o "Estado" autoritário ou o capitalismo das suas indiscutíveis contribuições para a reificação dos sujeitos e da cultura em geral. Mas é possível subestimar a capacidade, ainda que limitada, de reação dos sujeitos? Afinal, quem reagiu à repressão, por que motivo o fez? Castellani Filho (1988) bem demonstra que havia resistência, havia reação. Vitimar o professor é tirá-lo da sua condição de sujeito histórico, capaz de tornar-se criativo, no sentido mesmo de aqui- sição de autonomia para superar a condição de classe da sociedade burguesa, nem sempre tão demar-cada (Thompson, 1979).

Diante dessas considerações, outro estudo que merece destaque é o de Oliveira (1994). Polarizando a intervenção educativa da educação física brasileira em torno de uma pedagogia do consenso e uma pedagogia do conflito, o autor oferece-nos um balanço da produção intelectual sobre a educação física a partir dos anos 1980, momento em que considera terem emergido elementos críticos na educação física brasileira. Sua posição diante da polarização proposta é bastante emblemática daquilo que aqui denomino de abstracionismo. 0 autor reclama que

A ótica do consenso sustenta-se em princípios funcionalistas que só prevêem possibilidades para interação, continuidade, conservação, harmonia, equilíbrio e ajustamento sociais. A ideologia capitalista tende a tornar-se senso comum, restringindo o leque de opções das classes dominadas. Se perguntarmos a um pobre qual o sonho de sua vida, a resposta quase inevitável será: ser rico, ou seja, trocar de lado. 0 papel do professor, como intelectual orgânico que opta pelos desfavorecidos, é abrir o amplo leque de percepção daqueles que o cercam para as contradições do capitalismo, dando-lhes opções. A pedagogia do conflito é um trabalho de persuasão, no sentido gramsciano, para a superação do conhecimento do senso comum, ou seja, a filosofia das classes subalternas. Não se pode esperar que, espontaneamente, as massas despertem para as necessidades da verdadeira transformação social. Esse foi um dos maiores ensinamentos de Lenin. 0 trabalho pedagógico revolucionário implica obstaculizar a veiculação de valores burgueses, assim como preparar os trabalhadores para serem dirigentes em uma outra sociedade. A passagem para esse outro nivel de consciência é a catarsis gramsciana. (Oliveira, 1994, p. 185) 
Parece-me que também Oliveira vitimiza os professores. E bem ao gosto dos intelectuais, as classes dominadas aparecem no seu texto como incapazes de gerir suas vidas, necessitando, portanto, serem iluminadas pelos doutos membros da academia. Observe-se que o professor, nesse texto, também precisa ser esclarecido. Caso contrário ele não teria condições de conduzir a massa ao esclarecimento. Ocorre que imputar ao professor o papel de intelectual orgânico é simplificar em demasia a concepção gramsciana que não reduz o intelectual orgânico a uma pessoa, mas concebe-o como uma vontade coletiva. E essa vontade é histórica, ou seja, consciente do seu momento histórico real (Gramsci, 1991, p. 6). É claro que o esclarecimento, ainda que seja obscuro o que o autor entende por esse termo, não pode ocorrer sem o consórcio dos professores, se pensarmos nas práticas escolares. Porém, as abstrações em torno do papel do professor na transição para uma sociedade socialista conforme propõe Oliveira (1994, p. 187) desencarnam os individuos de sua materialidade concreta e histórica.

Na mesma linha de desenvolvimento de Oliveira, no trabalho de Carmo (1985) também é possivel perceber esse universo abstrato - não seria autoritário? - das teorizações acadêmicas sobre a prática dos professores:

0 competente e o incompetente fundam-se na concepção de mundo e não na forma como se apresenta este ou aquele indivíduo diante de um fenômeno. Assim, toda ação teórico-prática em educação física desprovida de uma consciência histórico-cultural de classe resultará apenas em mais uma das tantas inócuas ações pedagógicas tão comuns hoje em dia. Esta inocuidade não é gratuita nem fruto do acaso, ela é proposital e de alto poder conservador, principalmente porque, quanto pior for a veiculação do saber, pior será a apreensão pelo aluno e, conseqüentemente, mais fácil será a utilização do conhecimento como instrumento de dominação, pois uma ação pedagógica desenvolvida sem objetividade, sem raizes históricas e perspectivas do como deveria ser, leva a lugar nenhum.

Especificamente em educação física, necessita-se de professores com competência técnica, cientes do que fazer, como fazer e por que fazer, e conscientes politicamente, sabendo a quem estão servindo, quem é beneficiado com sua prática, enfim, professores que consigam ter uma visão de totalidade, na qual o importante é entender a inter-relação dinâmica das partes que compõem este todo, e não a simples justaposição dessas partes. (...)

Quando insistimos em colocar a questão da identidade social e política do professor de educação física não o fazemos gratuitamente. Agimos assim porque acreditamos ser este o primeiro passo rumo à consciência filosófica e de classe. (Carmo, 1985, p. 31)

Novamente estamos diante de uma série de considerações de como deveria se comportar o professor de educação física, de como deveria ser a prática pedagógica, enfim, de como deveria ser a realidade. É importante observar que, ainda que inúmeros autores e/ou estudos reivindicassem a histórica como tribunal de suas inquietações perante as determinações do mundo capitalista, a alternativa seria uma nova ordem social por definição boa, ou seja, a-histórica. Essa ordem social, assim como a prática real da educação física, pairaria em algum lugar asséptico, longe da "contaminação" humana. Os homens e mulheres capazes de soerguer esse mundo deveriam ser educados, preparados, formados, esclarecidos. E não raro alguns desses trabalhos apresentam-se como porta-vozes do "novo", como portadores da potência transformadora, ou seja, como os candeeiros capazes de iluminar todos aqueles que permanecem no obscurantismo de práticas reprováveis, uma vez que são práticas de "reprodução social". Em nome da crítica a um mundo efetivamente desumano e reificador 
estabeleceu-se um protocolo de intenções que desconsiderou por completo a prática humana concreta através da história, aquela que efetivamente se desenvolveu no cotidiano, por homens e mulheres reais.

Por fim, julgo interessante apontar ainda algumas das formulações propostas por Guiraldelli Jr. (1988) e Betti (1991), dois autores que estabeleceram, de pontos de vista diferentes, análises sobre o desenvolvimento histórico da educação física no Brasil e, mais precisamente, sobre as influências governamentais sobre a sua prática escolar nos anos da ditadura militar. Fiel à tradição crítica que abdicou da empiria, Guiraldelli Jr. tece considerações sobre os "usos" da educação física pelos governos militares. Para o autor

É preciso também notar que, se por um lado a educação física Competitivista era incentivada pela ditadura pós-64, pois tal concepção ia no sentido da proposta de um "Brasil-Grande", capaz de mostrar sua pujança através da conquista internacional, por outro lado, obviamente, esse não era o único interesse governamental ao endossar tal concepção.

Na verdade, o "desporto de alto nível”, divulgado pela mídia, tinha o objetivo claro de atuar como analgésico no movimento social. A preocupação com a possibilidade do aumento das horas de folga do trabalhador, que mesmo um sindicalismo amordaçado poderia conseguir, incentivava o governo a procurar no desporto a fórmula mágica de entretenimento da população. (Guiraldelli Jr., 1988, p. 31-2)

Uma das fontes de Guiraldelli Jr. para extrair suas conclusões é justamente a Revista Brasileira de educação física e Desportos minha fonte escrita privilegiada. E é interessante notar como o autor opera uma apropriação dos registros da Revista da forma que Thompson denominou de autoconfirmadora
(1981, p. 21). Guiraldelli Jr. não faz alusão ao rico debate que estava posto nas páginas da Revista debate que era internacional, e que remetia a uma consolidação do esporte que não tinha necessariamente a ver com a política do Brasil-Grande. Outra preocupação que esse autor não teve foi a de verificar o que se praticava antes desse período nas escolas brasileiras. Alguns dos professores por mim entrevistados criticam não só o governo, mas também a literatura, pela ênfase dada, por exemplo, ao Esporte para Todos (EPT) no período em questão. Segundo o professor Julio Lubachevski, verbi gratia as atividades que viriam a ser denominadas de EPT já eram desenvolvidas em Curitiba desde meados dos anos 1950, portanto, num período de exercício e vigência da frágil democracia brasileira, no qual o país não estava sob a égide dos militares. Assim, talvez seja exagero considerar a tese que afirma que o interesse primeiro da divulgação das atividades esportivas pelo governo fosse de "analgésico social", como conclui Guiraldelli Jr. 0 autor, a partir de algumas premissas que são mais ideológicas que epistemológicas, confirma suas inferências a partir de uma leitura apenas parcial dos documentos. Havia um debate na Revista por ele utilizada e havia denúncias da própria orientação esportiva para a educação física brasileira.

Já o caso de Betti (1991) não é o mesmo. Esse autor opera uma crítica à esportivização da educação física brasileira, no período, com base num profundo merguIho na legislação e na documentação oficial. Suas referências principais para tecer criticas às políticas educacionais do período são os trabalhos de Freitag (1986) e Romanelli (1986), duas obras de referência no campo educacional. A análise proposta por Betti por si só limita muito a compreensão do processo histórico, uma vez que a efetivação das políticas oficiais em práticas escolares não foi analisada. Ainda assim o autor afirma que 
0 conteúdo esportivo deu então uma nova coloração aos programas de educação física no Brasil, centrados na velha ginástica sueca e francesa. 0 esporte pareceu também ir ao encontro da ideologia propagada pelos condutores da Revolução de 1964: aptidão física como sustentáculo do desenvolvimento, espírito de competição, coesão nacional e social, promoção externa do país, senso moral e cívico, senso de ordem e disciplina. (Betti, 1991, p. 161)

Julgo ser importante indicar que o autor também utiliza alguns números da Revista por mim aqui estudada. Nesse caso, a crítica anteriormente dirigida a Guiraldelli Jr. permanece procedente na análise do estudo de Betti. Ou seja, o autor enxergou nas páginas da Revista apenas aqueles elementos que referendavam as suas críticas às políticas oficiais do periodo referido. 0 seu estudo não é tão incisivo quanto os anteriores naquilo que respeita à organização social. Certamente isso se justifica também pelo seu suporte teórico diferenciado, senão antagônico. Mas ainda assim suas análises não contemplam o desenrolar das políticas oficiais no plano das práticas concretas. Segundo os professores por mim entrevistados o esporte apareceu como uma alternativa ao descaso e à improvisação que então grassavam nas aulas de educação física. Para a grande maioria desses professores o esporte era uma atividade educativa por excelência. Assim sendo, ele era muito mais uma alternativa positiva do que um rebaixamento do valor formativo da educação física escolar. $\mathrm{Ou}$ seja, representava, mesmo, uma "nova coloração" para a educação física escolar. Quanto aos usos ideológicos que se podem fazer do esporte não podemos falar o mesmo de qualquer outra prática cultural? E os professores partilhavam dessa compreensão ou haveria compreensões diferentes em torno daquele uso?

Toda a construção teórica dessa produção aqui destacada - diferente nos seus objetivos e formas de análise - nega a história como movimento. Segundo Thompson:
A explicação histórica não pode tratar de absolutos e não pode apresentar causas suficientes, o que irrita muito algumas almas simples e impacientes. Elas supõem que, como a explicação histórica não pode ser Tudo, é portanto Nada, apenas uma narração fenomenológica consecutiva. É um engano tolo. A explicação histórica não revela como a história deveria ter se processado, mas porque se processou dessa maneira, e não de outra; que o processo não é arbitrário, mas tem sua própria regularidade e racionalidade; que certos tipos de acontecimentos (políticos, econômicos, culturais) relacionaram-se, não de qualquer maneira que nos fosse agradável, mas de maneira particulares e dentro de determinados campos de possibilidades; que certas formações sociais não obedecem a uma "lei", nem são os "efeitos" de um teorema estrutural estático, mas se caracterizam por determinadas relações e por uma lógica particular de processo. (1981, p. 61)

Certamente não podemos considerar os professores como sujeitos capazes de, por si só, transformar a realidade mediante sua prática pedagógica, como gostariam alguns dos autores anteriormente citados. Porém, os professores também não são ou foram vítimas; tampouco, foram coitados. Eles foram sujeitos que agiram e reagiram dentro de condições históricas concretas, bastante objetivas. Eles certamente não tinham a disponibilidade acadêmica para teorizar sobre o fim ou o início dos tempos. Vale lembrar que a crítica à condição ingênua ou alienada do professor está presente em inúmeros outros trabalhos, além desses aqui analisados, como é possível destacar em Medina (1983), Pereira (1988), Mariz de Oliveira (1988), Carvalho de Freitas (1991), Kunz (1991), Ferreira Neto (1993) e Gonçalves (1994).

As reformas educacionais de 1968 e 1971 são resultado de um processo contínuo de consolidação hegemônica, que não se deu sem profundos antagonismos, divergências 
embates e conciliações. Amplas parcelas da sociedade civil debatiam-se em torno do que representava a própria reorganização da cultura no pós-guerra, tanto no plano interno quanto no externo. Assim, o Estado brasileiro configurava-se como um amálgama de interesses diversos, não monolíticos, mas que, em última instância, não se propunha somente a fazer mecanicamente o jogo do capital internacional. Havia tensões que parecem ter sido desconsideradas ao longo da produção historiográfica. Mesmo porque se delineava toda uma outra configuração para a cultura brasileira, no sentido de sua modernização. 0 sentimento de nação moderna, forte, grande, difundido pelo Estado não trazia nada de novo; antes, era apenas uma redefinição de um processo iniciado já no século XIX de construção da nação brasileira, como nos indica Carvalho (1987). A própria dimensão política da produção do Instituto Superior de Estudos Brasileiros (ISEB) aponta nesse sentido. Resta saber em que medida o povo brasileiro estava preocupado com a invenção ou não da nação, proposta pelos governantes, para muito além de seu cotidiano mais imediato.

Uma parcela significativa da história da educação brasileira, da qual tomei apenas alguns exemplos, tem sido escrita à luz de deter-minantes estruturais, mas sem captar a lógica de processo impressa no desenvolvimento histórico. Ora, parece-me bastante difícil sustentar que havia consenso popular em torno do poder do Estado militarizado. Mas também não podemos afirmar que os governos militares não contavam com algum apoio entre a população. Creio que é necessário até mesmo indagar se o conjunto da sociedade civil sabia ou imaginava o que estava se passando em termos políticos no país e até que ponto os governos militares não tinham o apoio, ainda que velado, de significativas parcelas da população. Não se trata de negar a repressão, a exceção do regime e mesmo seu caráter perverso. Mas, se formos proceder a uma análise dos fatos concretos, poderíamos afirmar que socie- dade política teria perdido apoio da sociedade civil por conta da hipertrofia daquela, conforme indica Saviani, (1988, p. 95)? A historiografia mais recente sobre o golpe militar de 1964 tem enfatizado, inclusive, a própria tensão interna das Forças Armadas, que em hipótese alguma estavam coesas quanto aos rumos do país após os acontecimentos de 31 de março de 1964 (D’Araújo et al., 1994; Sodré, 1997; Gorender, 1997; Figueiredo, 1997). A análise da história pela sua configuração estrutural pouco espaço deixa para a configuração de formas particulares de correlação de forças, permeada pelas características próprias da cultura brasileira.

Parece-me que é também negada a historicidade da elaboração da reforma educacional da ditadura quando se aponta a continuidade entre o texto das várias reformas aprovadas - Lei 5.540/68 e Lei 5.692/71 - e a ordem socioeconômica gestada a partir de 1964. Creio que é o mínimo que se espera de um regime que pretende ampliar e consolidar o seu domínio, e a política educacional é pedra de toque nessa empreita. Dessa maneira, absurdo seria se não houvesse uma certa organicidade entre as reformas educacionais e o modelo socioeconômico. Mais: é importante destacar que as "vitórias" encetadas pelo regime militar foram expressão de um período de extrema ebulição política e de uma profunda reorganização cultural no Brasil. No vazio criado pelo fim do popu-lismo no início da década de 1960, aflora-ram as condições históricas necessárias para a reorganização das forças mais conservadoras, mas não sem uma permanente luta pelo poder em torno das questões educacionais e politicas mais amplas (lanni, 1974, 1997; Fernandes, 1982, 1997). Assim, o nexo entre a organização política, dinâmica cultural e a reorganização do sistema educacional só pode ser compreendido à luz da análise dos fatos concretos e não por categorizações externas à própria história. Estas, quando não apenas abstratas, correm o risco ainda de se tornarem arbitrárias. 
As análises aqui desenvolvidas têm a motivação clara e já manifesta de propiciar a retomada do debate acerca da configuração histórica da educação física escolar, mais precisamente, no período pós-1964. Os estudos escolhidos foram-no pelo grau de imagens e compreensões que ajudaram a consolidar na área, o que contribuiu, intencionalmente ou não, para que se cristalizasse uma concepção do desenvolvimento histórico da educação física rígido e algo mecânico. Uma concepção que cancela os sujeitos na sua potência criadora e obsta a compreensão da história como um processo dinâmico e multifacetado. 0 que se depreende dessa análise é a profunda característica generalizante e abstracionista de uma determinada produção em educação física no Brasil, no que tange aos estudos voltados para o ensino de educação física. A vinculação entre essa produção em educação física e a historiografia da educação brasileira é clara. Não podemos esquecer em absoluto o caráter situado e datado dessa produção. É preciso destacar também o papel que ela cumpriu na abertura de novas possibilidades de compreensão do fenômeno social e cultural que é a educação física.

Por outro lado, no que tange à compreensão da história da educação física, essa produção incorporou alguns "vícios" e alguns limites da pesquisa em educação à qual, na sua maior parte, esteve vinculada; o principal deles é olhar para a realidade de fora dela. $\mathrm{Na}$ perspectiva da teoria educacional, houve avanços significativos a partir da produção analisada. Mas, também, deu-se muita margem para equívocos quando se perdeu de vista o cotidiano da escola e duas das principais categorias utilizadas por praticamente todos os interlocutores aqui contemplados: a história como movimento contraditório e a sociedade como lugar de conflito. Tomado o Estado brasileiro do período analisado como títere do capitalismo internacional e dos arroubos conspiratórios da burguesia, restou fazer a apologia da revolução via educação, via a escola, como apare- ce em alguns trabalhos. Os documentos por mim analisados, entre os quais incluo os depoimentos dos professores de educação física, indicam o quanto as críticas desferidas contra os governos militares diante da opção pelo desenvolvimento precisam ser relativizadas, se tomadas como elemento apenas de juízo ideológico.

A profusão de teorias de desenvolvimento gestadas a partir do ISEB (Toledo, 1982) demonstra o quanto havia de divergências em torno do melhor projeto de desenvolvimento para o Brasil a partir da década de 1950. Num período de "crise de hegemonia" a vacância do poder abriu possibilidade para um regime autoritário mas, de forma alguma, monolítico e, em alguns dos seus estratos, profundamente nacionalista. Sendo assim, a ligação automática entre as políticas educacionais do governo brasileiro pós-1964 e o capitalismo internacional aponta para a desconsideração da particularidade do desenvolvimento cultural brasileiro.

0 que pretendo, então, é chamar a atenção para aquilo que considero como dois problemas presentes numa determinada maneira de escrever a história da educação e da educação física escolar no Brasil: a abstração e a generalização. No caso dos estudos analisados esses problemas ficam patentes quando transformam o Estado em um ente superior, que paira acima das mazelas humanas e dos interesses dos homens e dos grupos que representam. Ou o Estado é apresentado como pertencente a um só grupo social (classe ou fração de classe) ou é elevado à condição de supremo juiz das intenções humanas. Ora, o Estado não pode ser abstraído de sua orientação conflituosa, marcada por tensões, dissensões e conciliações. 0 Estado é uma construção histórica, determinada por uma correlação de forças que se consubstancia nos diversos interesses de classes e frações de classes contrários e antagônicos. E no campo da história não são tangíveis as leis gerais, as generalizações universais, uma vez que ela, a história, se confi- 
gura como um processo (Thompson, 1981). No plano educacional, é preciso investigar até que ponto o Estado freqüentou as salas de aula.

\section{A reorganização da educação física escolar: um amálgama de interesses}

Muitas evidências permitem inferir que a educação física brasileira naquele momento passava por um processo de renovação. Um universo bastante diverso de fontes indica que muitas vozes se levantavam para reivindicar um maior reconhecimento acadêmico e escolar para esse componente curricular. Desde a norma legal a partir da Lei 4024/61 (Diretrizes e Bases da Educação Nacional), reforçada na Lei 5692/71 e no decreto 69.450/71, passando pela expansão dos cursos de formação de professores em nivel superior, pela oferta de cursos emergenciais de formação de "recreacionistas", pelo incentivo ao intercâmbio internacional na área, pela emergência de um programa de publicações, pelo debate aberto no interior do Conselho Federal de Educação sobre a organização escolar desse componente curricular, pela qualificação em nível de mestrado e doutorado dos primeiros profissionais da área e desaguando na reivindicação dos professores escolares por uma definição mais precisa do espaço da educação física nos currículos, eram muitos os fóruns onde a educação física era ponto de pauta obrigatório. Não é a intenção desse artigo esgotar o tema, mesmo porque somente agora começam a surgir pesquisas de caráter histórico sobre a relação entre a constituição e a reorganização dos saberes escolares e as práticas docentes no âmbito da ditadura militar no Brasil. Mas no caso da educação física escolar é possível inferir algumas questões a partir do corpus documental por mim reunido e ao mesmo tempo infirmar uma certa tradição de leitura, a qual percorremos no tópico anterior. Essa leitura está fadada à obsolescência á medida que a pesquisa histórica tem demonstrado que inú- meros outros fatores determinam em larga medida a instituição, configuração e transformação dos saberes escolares ao longo do tempo. Portanto, privilegiarei aqui outras vozes que não as oficiais - consideradas como aquelas oriundas do aparelho estatal -, pretendendo com isso indicar o contraponto possível entre os múltiplos interesses em jogo na renovação da educação física escolar naquele período.

Como é impossível falar de um debate sobre a educação física no Brasil sem remetê-lo ao debate internacional, julgo ser importante destacar o cerne daquele debate: a relação entre uma educação física voltada para a educação integral do indivíduo e o esporte na sua forma acabada, ou seja, de rendimento ou de alto nível:

0 fato importante - o fato mundial - é que todos os países têm tomado perfeita consciência da importância humana e social da educação física. A confusão mais freqüente entre exercício físico e desporto de grande competição (amador ou profissional) é ainda obstáculo sério aos programas de educação física no mundo. 0 poder central (por demagogia), o público (por interesse imediato), mesmo os pais dos praticantes (por incompreensão) têm enorme tendência a ceder ao "desporto espetáculo". No entanto, devemos esperar que, um dia, os educadores físicos do mundo inteiro, intimamente ligados pelos princípios essenciais, saberão impor, em todos os países, uma educação física racional, estruturada para ser posta, verdadeiramente, ao serviço do homem e da sociedade. (Seurin apud Ramos, 1970, p. 26)

0 texto acima é indicativo de dois dos elementos por mim anteriormente apontados. 0 primeiro refere-se à preocupação mundial com o significado e a importância da educação física no processo educativo. Pierre Seurin, autor do texto acima, era membro da Fédération International de Éducacion 
Physique -FIEP, talvez a maior entidade internacional de educação física. Nos anos 1970 Seurin viria a ser presidente da entidade. 0 segundo elemento diz respeito à inserção do Brasil no debate internacional. Não por acaso optei por uma citação de segunda mão. Jair Jordão Ramos foi um dos mais destacados intelectuais da educação física brasileira. Naquele período, ele lançava mão de um trabalho de circulação mundial de um autor consagrado para referendar a sua própria posição sobre a renovação da educação física brasileira. Mas se os intelectuais brasileiros necessariamente recorriam à literatura internacional, como se posicionavam aqueles responsáveis pelas elaborações curriculares? Essa posição se expressava na preocupação com a definição e expansão do campo acadêmico da educação física brasileira, como é possível observar no texto abaixo:

Estabelecimento de uma política nacional de educação física. Propõe várias medidas para execução desses fins: instalações desportivas, material, formação intensiva de profissionais da especialidade, cursos intensivos regulamentados, zelo pela norma legal, saúde urbana e rural, plano nacional de comunicação (incremento da educação física), função de representação de professores de educação física nos órgãos, conselhos etc, orçamento.

TEMA B - unificação dos currículos dos diferentes cursos das escolas de educação física. Matérias obrigatórias e matérias optativas, diversificação dos programas dos diferentes cursos - currículo mínimo.

TEMA D - desenvolvimento da educação física por meio de pesquisas e de cursos de aperfeiçoamento em alto nível e de pós-graduação: solução de muitos dos nossos problemas. Esses cursos não devem ser limitados aos assuntos da ginástica e dos desportos, destacando-se, como tema prioritário, o relativo a métodos de pesquisa. A pesquisa deve ser despertada e incentivada entre alunos e professores de educação física, dentro das condições materiais disponíveis e essencialmente no campo das atividades da ginástica e dos desportos. (Vl Reunião de Diretores de Escolas de educação física, 1967)

Não emergia ali, conforme indica o texto acima, uma forte pressão para a elevação do statusinstitucional da educação física, a partir de uma série de considerações em torno de sua relevância social, da necessidade de desenvolvimento de pesquisa na área, o que requeria formação de professores e pesquisadores e alocação de recursos? E em linhas gerais a corporação dos professores, por meio de uma das suas associações, não destoava daquelas considerações:

- necessidade, cada vez maior, de dar ao educador uma formação de amplo e profundo caráter humano;

- revisão dos processos pedagógicos; estimular o educando a resolver situações novas com os recursos que o educador lhe fornecer; agir e reagir face aos problemas que lhe surgem;

- necessidade de pesquisar no campo da didática;

- que as autoridades governamentais solicitem a colaboração das entidades de classe dos diversos Estados da União, quando dos estudos dos problemas da formação dos professores de educação física;

- exige várias providências do Estado no tocante a valorização do profissional;

extensão da educação física a toda a comunidade;

- incentivo (política) (sic) aos recém formados;

- os programas das escolas de educação física devem ser orientados no sentido de criar no futuro professor o espírito e iniciativa do livre empreendimento;

- melhorar o nível do ensino especializado de educação física, facilitando os contatos 
da especialização com os centros mais adiantados do mundo;

- que sejam cumpridos fielmente o ditames do Decreto ro 69.450/71, por ser certo e de profunda liberalidade, sendo mesmo o mínimo a exigir, tendo em vista que a educação física, através dos exercícios físicos, dos desportos e das atividades ditas de recreação, representa a alegria, o prazer, a saúde física e mental da infância, da adolescência e dos adultos. (Recomendações do 111 Encontro de Professores de educação física da Guanabara, 1972)

E no plano da política miúdatambém emergiam preocupações com a educação física. Um exemplo pode ser tirado do primeiro programa de educação física da Prefeitura Municipal de Curitiba:

A elaboração do "Programa por Temporada" objetiva propiciar aos senhores Professores de educação física, a preparação dos seus alunos de modo planejado obedecendo a uma programação antecipada e definida, afastando deste modo processos improvisados, e sem uma seqüência pedagógica.

Nunca será possível realizar uma tarefa educacional se a mesma não for antecipada em seus objetivos e nos meios a serem utilizados.

Desta forma pretendemos acabar por vez com o regime de improvisação dentro das escolas municipais, fornecendo orientação educacional sistemática, formal e organizada dentro da conceituação moderna da educação. (1972, p. 18)

Esse texto é outra evidência de como as coisas mudavam naquele momento, pelo menos no que diz respeito à educação física em Curitiba. 0 Programa por Temporada despontava como uma alternativa à improvisação que grassava nas escolas municipais e ao descaso com a educação física escolar. Diante desse quadro organizou-se um programa que viria a ser conhecido como "Bíblia”, justamente pelo seu caráter de manual, de receituário. Mas esse caráter era constantemente subvertido à medida que os professores lançavam mão dos mais variados artifícios na sua prática cotidiana:

As crianças vinham para a escola; elas tinham aquela noção de vir para a escola para aprender a ler e escrever; jamais vinham para a escola para fazer educação física, jamais; isso não se cogitava. E essa fase de $5^{\text {a }}$ a $8^{\text {a }}$ série era de implantação recente, isso nos anos 70. Então, para as crianças que caminhavam em torno de 4 a 6 quilômetros para vir para a escola, chegar na escola para correr, para saltar, enfim, para fazer aquilo que eu havia aprendido que era importante, eles não achavam que realmente era importante, não é? Então, eu tive que usar de " $n$ " mecanismos de sedução para que eles passassem a gostar do conteúdo (...).

A gente adaptou a educação física a circunstâncias muito naturais. Por exemplo, o salto em extensão a gente fazia com as sombras do barranco por sobre a estrada; 0 salto em profundidade era saltar do barranco sobre a estrada; o salto em altura era saltar os galhos caídos sobre o barranco. (Massaneiro, 1998).

Esse pequeno conjunto de evidências diversas permite situar a configuração da educação física brasileira no âmbito das reflexões desenvolvidas por Goodson (1990):

Análises mais atentas das matérias escolares revela uma série de paradoxos inexplicados. Em primeiro lugar, o contexto escolar é, sob muitos aspectos, muito diferente do contexto universitário - problemas mais amplos de motivação do aluno, de capacidade e de controle necessitam ser considerados. A tradução da "disciplina” para a "matéria escol ar”, portanto, exige uma considerável adaptação (...). Em segundo lugar, as matérias escolares são, com freqüência, ou divorciadas de 
sua disciplina-base ou não tem uma disciplina-base. (Goodson, 1990, p. 234-235)

Se olharmos para o desenvolvimento histórico e para a realidade atual da educação física brasileira, creio ser possível referendar as considerações acima. E é ainda esse mesmo autor que nos dá elementos para compreender esse processo:

O grau de isolamento ou autonomia das matérias escolares pode ser visto, numa análise mais atenta, como estando relacionado aos estágios de evolução das matérias. Longe de serem derivadas de disciplinas acadêmicas, muitas matérias escolares precedem cronologicamente suas disciplinas-mãe: nessas circunstâncias a matéria escolar em desenvolvimento realmente causa a criação de uma base universitária para a "disciplina" de forma que professores secundários das matérias escolares possam ser treinados. (Goodson, 1990, p. 235)

Os debates promovidos no âmbito da educação física brasileira nos últimos quarenta anos têm evidenciado uma busca incessante pelo reconhecimento acadêmico, institucional e social. Diante de um campo de possibilidades - diferentes perspectivas do ensino da educação física na escola esse processo não se desenvolveu sem o consórcio, inclusive, da corporação dos professores de educação física, como já explorou Beltrami (1992). Daí a necessidade de localizarmos a experiência desses professores no âmbito daquilo que Thompson caracteriza como o diálogo entre o ser e a consciência social (1981, p. 17). As perspectivas diversas de agentes diversos estão pautadas por uma necessária e intrincada trama social e cultural, em que algumas tendências são suplantadas por outras, permanecendo as primeiras como potência histórica. Nesse processo os diferentes sujeitos, portadores de diferentes perspectivas, lançam-se à luta em torno daquilo que representaria a síntese mais aproximada dos seus interesses manifestos. 0 Estado que legislava, os pesquisadores que reclamavam recursos e os professores que exigiam um controle forte sobre aquilo que consideravam desmando das escolas (Beltrami, 1992), bem como lançavam mão dos mais variados artifícios para o seu trabalho cotidiano, como ficou patente nos textos acima. Todos esses sujeitos, portadores de amplo leque de interesses e reivindicações, de uma forma ou de outra estavam amalgamados naquele momento. Em suma, todos desejavam maiores e melhores recursos para o desenvolvimento de suas atividades no âmbito da educação física.

A atuação através da distribuição padronizada de recursos representa um processo de "tendência acadêmica" que angustia os subgrupos que promovem as matérias escolares. Por isso, áreas tão diversas como as de trabalho em madeira e metal, educação física, artes, estudos técnicos, contabilidade, costura e economia doméstica têm procurado melhoria de status, defendendo uma intensificação de exames e habilitações no estilo acadêmico. (Goodson, 1995, p. 37)

Nas falas contempladas nos limites desse trabalho - entidades internacionais/intelectuais da educação física, dirigentes de escolas superiores, legisladores e professores - vemos convergir uma série de orientações que determinariam os rumos da educação física escolar no Brasil pelo menos por vinte anos, o que infirma a tese de um Estado demiurgo determinando o lugar e a prática daqueles diferentes sujeitos na organização de uma prática cultural, a educação física. E essas orientações nada tinham de altruístas ou arbitrárias. Antes, faziam parte da correlação de forças determinada pelas condições objetivas dos sujeitos em uma determinada ambiência cultural e histórica. Partindo do 
pressuposto de Goodson (1990) de que o controle universitário não reflete um padrão continuo de dominação generalizada, é possível afirmar que

O conhecimento acadêmico de alto status ganha seus aderentes e aspirantes menos através do controle dos currículos que socializam que através da conexão bem estabelecida com padrões de alocação de recursos e com o trabalho associado e as perspectivas de carreira que esses asseguram. 0 estudo das matérias escolares em evolução dirige nossa atenção para a evolução de padrões de alocação de recursos. 0 trabalho recente de $M$. Smith tem demonstrado claramente quão frutífero poderia ser esse enfoque ao substituir cruas noções de dominação por padrões de controle nos quais os grupos subordinados podem ser vistos ativamente em ação. (Goodson, 1990, p. 252)

Assim, é possível concluir que, a menos que houvesse o consentimento dos diversos agentes sociais, as políticas educacionais não teriam condições de consolidar-se no interior das escolas. Até porque a escola pode desenvolver uma dinâmica própria de organização que, sem dúvida, relaciona-se com o plano cultural mais amplo, mas que interage com ele para manifestar-se e para autogerir-se. Assim, não podemos falar genericamente de uma conformação do sistema educacional pelo Estado autoritário. Primeiramente, então, prefiro caracterizar as iniciativas oficiais como sendo "do governo" e não "do Estado". Mas, apesar da influência governamental, ainda assim, no caso da renovação da educação física brasileira, a sua corporação de especialistas ajudou a conformar o sistema educacional, mormente no que se refere às práticas escolares. Da tensão entre o "imposto" pela via legal e aquilo que foi assimilado e produzido por parcelas da sociedade, emergia a prática cotidiana dos educadores escolares.

Para essa produção acadêmica por mim indicada, com a qual não pretendi exaurir o tema, representativa de uma forma de "ler" a história da educação no Brasil, caberia à escola, com sua função estritamente reprodutora, única e exclusivamente a reificação dos indivíduos e da cultura no interesse da manutenção/ reprodução da ideologia burguesa. Para aqueles que pretendem uma sociedade mais igualitária a escola seria, então, perfeitamente dispensável. Por que continuamos, então, a estudá-la e a trabalhar nela? Analisemos a escola por dentro de suas particularidades e de suas determinações próprias. Deixemos as generalizações e as abstrações para aquilo que não tem existência concreta na história da educação e da educação física.

\section{Referências bibliográficas}

6ミ REUNIÃODEDIRETORESDEESCOLASDEEDUCAÇÃOFÍSICA 1968, Vitória.Boletim Técnico Informativo.Brasília, n. 1, p. 50 59.

ARANHA Lúcia.Pedagogia histórico-crítica o otimismo dialético em educação. São Paulo: EDUC. 1992.158p.

AZANHA José Mário Pires.O abstracionismo pedagógico:uma idéia de pesquisa educacional. São Paulo. Edusp, 1992. p. 4156.

BARREIRA Luiz Carlos. História e historiografiaas escritas recentes da história da educação brasileira (1971-1988). Campinas; 1995. 258p. Tese (Doutorado) - Faculdade de Educação, Universidade de Campinas.

BEHOSTE, Bruno .Resume de l'exposé de Bruno Belhoste au Service d'Histoire de l'Éducation.Paris: INRP, 1995. 
BERCITQ, Sônia de Deus Rodrigues. Educação Física e construção nacional. In:FERREIRANETQ, Amarílio (Org .) .Pesquisa histórica na educação física brasileira.Vitória: CEFD/UFES, 1996. p. 145-160.

BETTI Mauro.Educação Física e sociedade São Paulo: Movimento, 1991. 184p.

BRACHT, Valter .Educação Física e aprendizagem socia/Porto Alegre: Magister, 1992. 122p.

BUFFA Este r ; Nbsßıł Paolo . Aeducaçãonegada introdução ao estudo da educação brasileira contemporânea. São Paulo: Cortez, 1991.

CAPMD, Apolônio Abádio do.Educação física competência técnica e consciência política em busca de um movimento simétrico. Uberlândia:UFU, 1985.54p.

CARVALHQ José Murilo de.Os bestializados.São Paulo: Companhia das Letras, 1987. 196p.

CARVALHODEFREITAS Mauri.A miséria da educação física.Campinas: Papirus, 1991. 166p.

CASTELLANIFLLHQ, Lino . Educação física no Brasil:a história que não se conta. Campinas: Papirus, 1988. 225p.

CASTRQ Celso.In corpore sanoos militares e a introdução da educação física no Brasil Antropolítica Rio de Janeiro, n.2, p. 61 $78,1997$.

CHERVEl, André. História da disciplinas escolares: reflexões sobre um campo de pesquisa.Teoriae Educação Porto Alegre, n. 2 , p. 177-229, 1990.

CHEVALARD, Yves.La transposición didácticaBuenos Aires: Aique, 1991.186p.

QUNHA Luis Antonio;GOES Moacyr de.Ogolpe na educação Rio de Janeiro: Jorge Zahar, 1994. 95p.

CURITIBA Prefeitura Municipal.Programade educaçãofísica portemporadas,1972-1984. Curitiba: [1.n.] 1984.

D’ARAÚJO, Maria Celina et al. (Orgs.).Visões do golpe.a memória militar sobre 1964. Rio de Janeiro: Relume-Dumará, 1994. $256 p$.

ÆRNANDES Florestan.A ditadura em questão São Paulo: T. A. Queiroz, 1982. 164p.

. 0 significado da ditadura militar. In:TOLDQ Caio Navarro de (Org.).1964 visões críticas do golpe. Campinas: Editora Unicamp, 1997. p. 141-148.

FERREIRANETQ Amarílio. A formação política do professor de Educação Física. In: VOTRE, Sebastião (Org.).Ensino e avaliação em educação física São Paulo: Ibrasa. 1993. p. 19-50.

A pedagogia no exército e na escola Aracruz, ES: Facha, 1999. 162p.

FERREIRA Marieta de Moraes;AMADQ Janaína.Usos e abusos da históriao ra I.Rio de Janeiro: Fundação Getúlio Vargas, 1996. $277 p$.

FIGUEIREDQ Argelina. Democracia e reformas: a conciliação frustrada. In:TOLDQ Caio Navarro de (Org.).1964 visões críticas do golpe. Campinas: EditoraUnicamp, 1997. p. 47-54.

FREITAG Bárbara.Escola, estado e sociedade São Paulo: Moraes, 1986.142 p.

GPMANQ José Wellington .Estado militar e educação no Brasil (1964-1985).São Paulo: Cortez; Campinas: Editora Unicamp, 1993.297p.

GOEUNER Silvana Vilodre. 0 Método francês e a militarização da educação física na escola brasileira. In:FERREIRANETQ, Amarílio (Org). Pesquisa histórica na educação física brasileira Vitória: CEFD/UFES, 1996. p. 123-144. 
GONÇALVES Maria Augusta Salin.Sentir, pensar, agircorporeidade e educação. Campinas: Papirus, 1994. 196 p.

GO0DSON Ivor. Tornando-se uma matéria acadêmica: padrões de explicação e evolução.Teoria \& Educaçãa Porto Alegre, n. 2 , p. 230-254, 1990.

. La construcción social del curriculum: possibilidades y ambitos de investigación de la historia del curriculum Revista de Educación Madri, n. 295, p. 7-37, mayo-ago.1991.

Historia del currículum la construcción social de las disciplinas escolares. Barcelona: Ediciones Pomares-Corredor, 1995a.239p.

. Currículoteoria e história. Petrópolis: Vozes, 1995b. 140p.

. Dar voz ao professor: as histórias de vida dos professores e o seu desenvolvimento profissional. In:NÓvOA António. Vidas de professores Porto: Porto Editora, 1995c. p. 63-78.

GRAMSCI Antonio.Maquiavel, a política e o estado moderno Rio de Janeiro: Civilização Brasileira, 1991. 444p.

GORENDR Jacob. Era o golpe de 64 inevitável? In:TOLDD, Caio Navarro de (Org.). 1964 visões críticas do golpe. Campinas: Editora Unicamp, 1997. p. 109-116.

GUIRALDELLUr. , Paulo.Educação física progressista São Paulo: Loyola, 1988. 63p.

História da educação São Paulo: Cortez, 1994. 234p.

IANNI Octavio.Imperialismo e culturaPetrópolis: Vozes, 1974.

. As estratégias de desenvolvimento. In:TOLEDQ, Caio Navarro de (Org.).1964 visões críticas do golpe. Campinas: Editora Unicamp, 1997. p. 137-140.

KUNZ, Elenor .Educação Física ensino e mudanças. Ijuí: Unijuí Editora, 1991. 206p.

LBBÂNEQ José Carlos.Democratização da escola pública: a pedagogia crítico-social dos conteúdos São Paulo: Loyola, 1989.

LIMA Lenir Miguel de.Os militares, o populismo e suas influências na Educação física em Goiás.Goiânia; 1991. Dissertação (Mestrado) - Programa de Pós-Graduação em Educação da Universidade Federal de Goiás.

MARIZDEOLIVEIRA,José Guilmare t al Educação física e o ensino de $1^{\circ}$ grau.São Paulo: Edusp, 1988. 67p.

MASSANERQ Idelzi Terezinha. [Entrevista concedida no dia 30/03/1998]. [s.h.: s.n.] 1998.

MEDINA João Paulo de Subirá.A Educação física cuida do corpo... e mente.Campinas: Papirus, 1983. 96p.

METODOLOGIADOENSINODEEDUCAÇÃOFÍSICA São Paulo: Cortez, 1992. 117p.

OLIVEIRA Marcus Aurelio Taborda de. Elementos para uma análise da renovação da Educação física escolar no Brasil durante a ditadura militar (1964-1985): uma contribuição para a história das disciplinas. In:30 CONGRESSOLUSO-BRASILEIRODE HISTÓRIADAEDUCAÇÃO, 2000, Coimbra.Aná s .Coimbra: [s.n.]2000. p. 170.

A Revista Brasileira de Educação Física e Desportos e a experiência cotidiana de professores da Rede Municipal de Ensino de Curitiba entre a adesão e a resistência. São Paulo; 2001. 399p. Tese (Doutorado) - Programa de Estudos PósGraduados em História e Filosofì da Educação da PUC de São Paulo.

OLIVEIRA Vitor Marinho.Consenso e conflito na educação física brasileira Campinas: Papirus, 1994.203p.

PAIVA Fernanda.Ciência e poder simbólico no Colégio Brasileiro de Ciências do Esporte Vitória: CEFD/UFES, 1994. 254p. 
PALAFOX Gabriel Humberto Muñoz.Educação física no Brasilaspectos filosóficos-pedagógicos subjacentes à política nacional em ciência e tecnologia para esta área no período 1970-1985. São Paulo; 1990.121p. Dissertação (Mestrado) -Programa de Estudos Pós-Graduados em Educação da PUC de São Paulo.

PEREIRA Flávio Medeiros.Dialética da cultura físicaSão Paulo: Ícone, 1988.291p.

RACHI Kiyos hi .Educação escolar brasileira:um reexame dos estudos tendo por centro de análise a categoria de "contradição". São Paulo; 1990. 292p. Dissertação (Mestrado) - Programa de Estudos Pós-Graduados em História e Filosofia da Educação daPUC de São Paulo.

RAMOS Jayr Jordão. Panorama mundial da educação física e atividades correlatas. Revista Brasileira de Educação Física e Desportos Brasília, n. 9, p. 18-26, 1970.

ENCONTRODEPROFESSORESDEEDUCAÇÃOFÍSICADAGUANABARA 2 . 1972, Niterói .Recomendações.Nite rói : Associação dos Professores de Educação Física da Guanabara, 1972.

ROMANEU Otaíza de Oliveira.História da educação no Brasil(1930-1973).Petrópolis: Vozes, 1986. 267p.

SAVIANI Dermeval.Escola e democracia.São Paulo: Cortez/Autores Associados, 1983. 96p.

Política e educação no Brasil.São Paulo: Cortez/Autores Associados, 1987. 163p.

_Educação do senso comum à consciência filosófica. São Paulo: Cortez/Autores Associados, 1989. 224p.

SOARES Carmen Lúcia.Educação física.raízes européias e Brasil. Campinas: Autores Associados, 1993. 167p.

Imagens da educação no corpo.Campinas: Autores Associados, 1998. 145p.

SODRÉ, Nelson Werneck. Era o golpe de 64 inevitável? In: TOLED0, Caio Navarro de (org.).1964 visões críticas do golpe. Campinas: EditoraUnicamp, 1997.p. 103-108.

SOUSA Eustáquia Salvadora de.Meninos, à marcha! Meninas, à sombra!:a história do ensino da Educação física em Belo Horizonte (1897-1994). Campinas; 1994. Tese (Doutorado) - Programa de Pós-Graduação em Educação da Unicamp.

SOUSA Eustáquia Salvadora; VAGO, Tarcísio Mauro (Orgs.).Trilhas e partilhas.educação física na cultura escolar e nas práticas sociais. Belo Horizonte: Cultura, 1997.387p.

TANI Go. Educação física escolar no Brasil: seu desenvolvimento, problemas e propostas. In: Seminário Brasileiro em Pedagogia do Esporte, 1998, Santa Maria. Anais do Seminário Brasileiro em Pedagogia do Esporte. Santa Maria: [s.n.], 1998. p. 120127.

THOMPSON Edward Palmer.Tradición, revuelta y consciencia de clase.Barcelona: Crítica, 1979. 318p.

A miséria da teoria.Rio de Janeiro: Zahar, 1981.231p.

Senhores e caçadores.Rio de Janeiro: Paz e Terra, 198 .432p.

TOLDQ, Caio Navarro.ISEB.fábrica de ideologias. São Paulo: Ática, 1982. 195p.

(Org.).1964 visões críticas do golpe. Campinas: Editora Unicamp, 1997. 168p.

VAGQ Tarcísio Mauro.Cultura escolar, cultivo de corpos educação physica e gymnastica como práticas constitutivas dos corpos de crianças no ensino público primário de Belo Horizonte (1906-1920). São Paulo; 1999. 315p. Tese (Doutorado) -Faculdade de Educação daUSP. 
VIEIRA Carlos Eduardo.O historicismo gramsciano e a pesquisa em educação São Paulo; 1994. 248p. Dissertação (Mestrado) - Programa de Estudos Pós-Graduados em História e Filosofia da Educação da PUC de São Paulo.

VIEIRA Evaldo Amaro.Estado e miséria social no Brasil.de Getúlio a Geisel (1951-1978). São Paulo: Cortez, 1983. 240p.

WAPDE, Mirian Jorge. Contribuições da história para a educação.INEP, Brasília, v. 9, n. 47, p. 3-11, 1990.

Recebido em 23.05.2001

Aprovado em 27.03.2002

Marcıs Aurélio Taborda de Oliveiraé doutor em História e Filosofia da Educação pela PUC/SP; professor do Departamento de Teoria e Prática de Ensino e do programa de Pós-Graduação em Educação, linha de História e Historiografia da Educação, da Universicade Federal do Paraná. 